\title{
Use of nitrogen sufficiency index to estimate topdressing doses for common bean ${ }^{1}$
}

\author{
Gustavo Henrique do Nascimento ${ }^{2}$, Silvino Guimarães Moreira², \\ Fábio Aurélio Dias Martins ${ }^{3}$, Guilherme Vieira Pimentel ${ }^{2}$, Junior Cézar Resende Silva ${ }^{2}$
}

\section{ABSTRACT}

Portable chlorophyll meters can be used to improve the prediction of nitrogen $(\mathrm{N})$ doses for common bean. This study aimed to evaluate two chlorophyll meters (Minolta SPAD-502 and ClorofiLOG CFL 1030) to predict topdressing N doses for the Pérola, TAA Gol and BRSMG Uai cultivars and for the VR 20 line. Eight field experiments (four genotypes and two devices) were carried out in a randomized blocks design, with four replicates, being the treatments topdressing $\mathrm{N}$ applications corresponding to four nitrogen sufficiency indices. There were discrepancies between the indices obtained by the different devices for the same genotype, as well as among those obtained with the same device for the different genotypes studied. Thus, when the index is used to define the $\mathrm{N}$ doses, the genotype and the chlorophyll meter used must be considered. In addition, the recommended index of $95 \%$ should not be generalized to all the cultivars and should be reduced.

KEYWORDS: Phaseolus vulgaris L., chlorophyll meter, nitrogen fertilization.

\section{INTRODUCTION}

Common bean has an extreme socioeconomic importance in Brazil, where it is grown in an area of 2,946,000 ha, with an estimated production of $2,973,000 \mathrm{t}$ for 2021, resulting in a national average yield of $1,009 \mathrm{~kg} \mathrm{ha}^{-1}$ (Conab 2021).

Among the factors that negatively affect the common bean yield in Brazil is the lack of adequate information for the management of nitrogen $(\mathrm{N})$ fertilization for the main cultivars planted by farmers (Santi et al. 2006). For common bean, $\mathrm{N}$ is the most required nutrient and, although the crop has a high

\section{RESUMO}

Índice de suficiência de nitrogênio na estimativa de doses em cobertura para feijoeiro

Clorofilômetros portáteis podem ser utilizados para melhorar a previsão de doses de nitrogênio $(\mathrm{N})$ em feijoeiro. Objetivou-se avaliar dois clorofilômetros (Minolta SPAD-502 e ClorofiLOG CFL 1030) para predizer doses de N em cobertura para as cultivares Pérola, TAA Gol, BRSMG Uai e para a linhagem VR 20. Oito experimentos de campo (quatro genótipos e dois dispositivos) foram conduzidos em delineamento de blocos casualizados, com quatro repetições, cujos tratamentos consistiram na aplicação de $\mathrm{N}$ em cobertura correspondendo a quatro índices de suficiência de nitrogênio. Houve discrepâncias entre os índices obtidos pelos diferentes dispositivos para o mesmo genótipo, bem como entre os obtidos com o mesmo dispositivo para os diferentes genótipos estudados. Assim, quando o índice é utilizado para definir as doses de $\mathrm{N}$, deve-se considerar o genótipo e o clorofilômetro utilizado. Além disso, o índice recomendado de $95 \%$ não deve ser generalizado para todas as cultivares e deve ser reduzido.

PALAVRAS-CHAVES: Phaseolus vulgaris L., clorofilômetro, adubação nitrogenada.

capacity to establish symbiotic associations with bacteria of the Rhizobium genus, when targeting grain yields higher than $2,500 \mathrm{~kg} \mathrm{ha}^{-1}$ the biological $\mathrm{N}$ fixation alone does not supply the entire $\mathrm{N}$ demand of the crop (Pelegrin et al. 2009); thus, it is necessary to supply the nutrient using nitrogen fertilizers.

Accurate $\mathrm{N}$ fertilization recommendations are hampered by the complex $\mathrm{N}$ dynamics in the soil, which may result in a dose lower than the crop demand, thus limiting grain yield, or an excessive dose, which may not only increase the risk of environmental contamination but also compromise the profit of producers (Silveira et al. 2003). The

\footnotetext{
${ }^{1}$ Received: July 06, 2021. Accepted: Oct. 07, 2021. Published: Dec. 07, 2021. DOI: 10.1590/1983-40632021v5169571.

${ }^{2}$ Universidade Federal de Lavras, Departamento de Agricultura, Lavras, MG, Brasil.

E-mail/ORCID: gustavohn@outlook.com/0000-0002-3087-4361; silvinomoreira@ufla.br/0000-0002-3631-0305; guilherme.pimentel@ufla.br/0000-0001-9849-6427; junior.silva2@estudante.ufla.br/0000-0001-6427-6741.

${ }^{3}$ Empresa de Pesquisa Agropecuária de Minas Gerais, Lavras, MG, Brasil. E-mail/ORCID: fabio.aurelio@epamig.br/0000-0002-6776-617X.
} 
combination of these factors, together with the high cost of $\mathrm{N}$ fertilizers, has triggered interest in developing management techniques to maximize the $\mathrm{N}$ use efficiency by common bean plants (Amado et al. 2000). Thus, chlorophyll meters began to be studied as tools to aid in decision making about when and how much $\mathrm{N}$ to supply as topdressing in common bean cultivation (Barbosa Filho et al. 2008, Barbosa Filho et al. 2009, Maia et al. 2013, Silveira \& Gonzaga 2017).

The use of chlorophyll meters is based on the positive correlation between the concentrations of chlorophyll and $\mathrm{N}$ in leaves (Barbosa Filho et al. 2008). However, different factors may affect the relative chlorophyll indices measured by these devices (Silveira \& Gonzaga 2017). Thus, the $\mathrm{N}$ sufficiency index (NSI) has been used, whose purpose is to isolate the effect of the $\mathrm{N}$ concentration in leaves from other factors that may influence the readings, and thus assist in estimating the $\mathrm{N}$ dose to be applied as topdressing (Hussain et al. 2000).

The NSI is determined from chlorophyll meter readings of a reference plot, which consists of an area that received a high $\mathrm{N}$ dose to avoid the onset of $\mathrm{N}$ deficiency. According to Carvalho et al. (2012), the time interval between the fertilization of the reference area and the performance of readings to obtain the NSI must be of at least 10 days, a period necessary for the plants to absorb the supplied $\mathrm{N}$ and transport it to the leaves. After this period, readings are performed in all plots, i.e., in previously fertilized areas (reference plot) and in areas to be fertilized. The NSI is calculated from the values obtained by the measurement device.

According to Barbosa Filho et al. (2009), if an NSI of $90 \%$ is obtained for common bean, the index can be considered adequate and fertilization is not necessary. Maia et al. (2012) consider that common bean plants still require fertilization when the obtained NSI is $90 \%$. Silveira \& Gonzaga (2017) argue that, in addition to defining the most appropriate NSI for common bean plants, the amount of $\mathrm{N}$ to be supplied as topdressing should be established, and that the NSI for common bean plants is equal to $95 \%$ and the amount of $\mathrm{N}$ to be applied as topdressing should be of $11-15 \mathrm{~kg} \mathrm{ha}^{-1}$ for each $1 \%$ below an NSI of $95 \%$. However, the variations among the results found in the literature show the need for further clarification of which NSI is most suitable for common bean plants.
Thus, this study aimed to evaluate the potential use of two portable chlorophyll meters as an auxiliary tool in the definition of topdressing $\mathrm{N}$ doses for common bean cultivars of the Carioca group (Pérola, TAA Gol and BRSMG Uai) and for the VR 20 line of the red group.

\section{MATERIAL AND METHODS}

The experiments were performed in the $2017 / 2018$ crop season (spring/summer), at the Universidade Federal de Lavras, in Lavras, southern Minas Gerais state, Brazil (-21.185727S; -44.998992W).

A total of eight experiments were carried out, corresponding to the combination of three Cariocatype grains (Pérola, BRSMG Uai and TAA Gol) and one red common bean line (VR 20) with two portable chlorophyll meters (Minolta SPAD-502 and ClorofiLOG CFL 1030).

The experiments were set up under no-tillage conditions, in an area covered with corn straw, where the soil is classified as "Latossolo VermelhoAmarelo Distrófico típico" (Santos et al. 2018) or Typic Hapludox (USDA 2014). A composite soil sample was collected from the $0-20 \mathrm{~cm}$ layer before sowing, showing the following attributes: $\mathrm{pH}\left(\mathrm{H}_{2} \mathrm{O}\right)=5.2 ; \mathrm{P}\left(\right.$ Mehlich $\left.^{-1}\right)=12.5 \mathrm{mg} \mathrm{dm}^{-3}$; $\mathrm{K}=120.5 \mathrm{mg} \mathrm{dm}^{-3}$; organic matter $=2.0 \mathrm{dag} \mathrm{kg}^{-1}$; $\mathrm{Ca}=2.3 \mathrm{cmol}_{\mathrm{c}} \mathrm{dm}^{-3} ; \mathrm{Mg}=0.6 \mathrm{cmol}_{\mathrm{c}} \mathrm{dm}^{-3} ; \mathrm{Al}=$ $0.04 \mathrm{cmol}_{\mathrm{c}} \mathrm{dm}^{-3} ; \mathrm{H}+\mathrm{Al}=4.8 \mathrm{cmol}_{\mathrm{c}} \mathrm{dm}^{-3}$; cation exchange capacity $=8.01 \mathrm{cmol}_{\mathrm{c}} \mathrm{dm}^{-3}$; base saturation $=$ $40.5 \% ; \mathrm{Zn}=4.88 \mathrm{mg} \mathrm{dm}^{-3} ; \mathrm{Fe}=71.1 \mathrm{mg} \mathrm{dm}^{-3} ; \mathrm{Mn}=$ $10.0 \mathrm{mg} \mathrm{dm}^{-3} ; \mathrm{Cu}=1.0 \mathrm{mg} \mathrm{dm}^{-3} ; \mathrm{B}=0.29 \mathrm{mg} \mathrm{dm}^{-3}$; $\mathrm{S}=0.74 \mathrm{mg} \mathrm{dm}^{-3}$.

A soil correction was performed three months before sowing, to increase the base saturation to $70 \%$, by applying $3 \mathrm{t} \mathrm{ha}^{-1}$ of limestone. The sowing fertilization was carried out with $270 \mathrm{~kg} \mathrm{ha}^{-1}$ of an NPK (09-38-00) mixture (24.3 $\mathrm{kg} \mathrm{ha}^{-1}$ of N; $102.6 \mathrm{~kg} \mathrm{ha}^{-1}$ of $\mathrm{P}_{2} \mathrm{O}_{5}$ ) associated with $18 \%$ of sulfur $\left(48.6 \mathrm{~kg} \mathrm{ha}^{-1}\right), 0.15 \%$ of boron $\left(405 \mathrm{~g} \mathrm{ha}^{-1}\right)$, $0.15 \%$ of copper $\left(405 \mathrm{~g} \mathrm{ha}^{-1}\right), 0.45 \%$ of manganese $\left(1,215 \mathrm{~g} \mathrm{ha}^{-1}\right)$ and $0.45 \%$ of zinc $\left(1,215 \mathrm{~g} \mathrm{ha}^{-1}\right)$. The potassium fertilization was performed in the total area after sowing with $50 \mathrm{~kg} \mathrm{ha}^{-1}$ of $\mathrm{K}_{2} \mathrm{O}$. It should be noted that the fertilization was performed according to the soil analysis results, following recommendations by Souza \& Lobato (2004).

The sowing took place on November 08 (2017), using a randomized blocks design with four 
replicates, and the treatments were determined as a function of the N sufficiency index (NSI), being four NSIs proposed for each of the common bean genotypes and each chlorophyll meter. A spacing of $0.6 \mathrm{~m}$ between the planting rows was used, and the spacing between plants was defined according to the size characteristics presented by each genotype. Thus, 11 seeds $\mathrm{m}^{-1}$ were planted for the Pérola cultivar, 17 seeds $\mathrm{m}^{-1}$ for the TAA Gol cultivar and 14 seeds $\mathrm{m}^{-1}$ for the BRSMG Uai cultivar and the VR 20 line. Each experimental plot consisted of four 5-m-long rows, and the two central rows were considered the useful area.

The reference areas were established on November 23 (2017), eight days after the plants emergence (November 15, 2017). At this moment, in a plot consisting of four 5-m-long rows, $150 \mathrm{~kg} \mathrm{ha}^{-1}$ of $\mathrm{N}$ were applied as topdressing using urea $(45 \%$ of $\mathrm{N})$ (Silveira \& Gonzaga 2017), with manual application between the planting rows.

Readings with the chlorophyll meters were performed after the opening of the third trifoliate leaf (stage V4), on December 06 (2017), thirteen days after the implementation of the reference areas. The readings (one per leaflet) were carried out in five plants per plot, at the first mature trifoliate leaf from the apex of each sampled plant, and in the reference areas which had been previously fertilized, totaling 15 readings per plot.

After obtaining the relative chlorophyll indices for all the plots to be fertilized and for the reference area of each genotype, the NSI was calculated using the formula NSI $(\%)=$ (mean of the readings of the plot to be fertilized/mean of the readings of the reference plot) x 100 .
This procedure was performed for each of the chlorophyll meters tested, and a common reference plot was used for both the devices when analyzing the same genotype. According to the genotype-specific NSI obtained with each of the devices used, four desired NSIs were stipulated as it follows: the difference between the index obtained from the readings and the NSI of $95 \%$ (defined as the maximum NSI to be achieved) was calculated (Silveira \& Gonzaga 2017), the value of the difference was divided into four equal intervals, and these intervals were sequentially added to the NSI obtained from the readings. The following is an example of how the four NSIs were defined: if an NSI of $87 \%$ was obtained from the readings and an NSI of $95 \%$ was defined as the maximum value to be achieved, the difference between them ( $8 \%)$ was divided into four equal intervals. Thus, the sequential sum of this interval (2\%) to the NSI of $87 \%$ would result in indices of $\mathrm{NSI}_{1}=89 \%, \mathrm{NSI}_{2}=$ $91 \%, \mathrm{NSI}_{3}=93 \%$ and $\mathrm{NSI}_{4}=95 \%$, which were then evaluated. Calculation example: $\mathrm{NSI}_{1}=$ obtained $\mathrm{NSI}+[($ obtained NSI - defined NSI $) / 4]$ and $\mathrm{NSI}_{2}=$ $\mathrm{NSI}_{1}+[($ obtained NSI - defined NSI $)] / 4$.

After defining the NSI to be achieved, N topdressing was performed on December 08 (2017) in the eight experimental plots, using urea as the $\mathrm{N}$ source. As discussed by Silveira \& Gonzaga (2017), for each $1 \%$ lower than the NSI, $15 \mathrm{~kg} \mathrm{ha}^{-1}$ of $\mathrm{N}$ were applied. Table 1 shows the relationship among the genotypes, the devices used, the NSIs evaluated and the corresponding $\mathrm{N}$ doses applied as topdressing, at the V3 phenological stage.

Harvesting was performed according to the maturity presented by the genotype under evaluation.

Table 1. Genotypes, chlorophyll meters (Minolta SPAD-502 and ClorofiLOG CFL 1030), nitrogen sufficiency indices (NSI) and N doses applied as topdressing for the experiments conducted during the 2017/2018 season.

\begin{tabular}{|c|c|c|c|c|c|c|c|}
\hline \multicolumn{2}{|c|}{ TAA Gol } & \multicolumn{2}{|c|}{ Pérola } & \multicolumn{2}{|c|}{ BRSMG Uai } & \multicolumn{2}{|c|}{ VR 20} \\
\hline NSI (\%) & $\mathrm{N}$ dose $\left(\mathrm{kg} \mathrm{ha}^{-1}\right)$ & NSI $(\%)$ & $\mathrm{N}$ dose $\left(\mathrm{kg} \mathrm{ha}^{-1}\right)$ & NSI (\%) & $\mathrm{N}$ dose $\left(\mathrm{kg} \mathrm{ha}^{-1}\right)$ & NSI $(\%)$ & $\mathrm{N}$ dose $\left(\mathrm{kg} \mathrm{ha}^{-1}\right)$ \\
\hline \multicolumn{8}{|c|}{ SPAD-502 } \\
\hline 81 & 75 & 81 & 62 & 92 & 23 & 89 & 29 \\
\hline 86 & 150 & 86 & 137 & 93 & 38 & 92 & 59 \\
\hline 90 & 210 & 90 & 197 & 94 & 53 & 93 & 89 \\
\hline 95 & 285 & 95 & 272 & 95 & 68 & 95 & 119 \\
\hline \multicolumn{8}{|c|}{ CFL 1030} \\
\hline 85 & 57 & 88 & 40 & 88 & 37 & 90 & 29 \\
\hline 88 & 102 & 90 & 70 & 90 & 67 & 92 & 59 \\
\hline 92 & 162 & 93 & 115 & 93 & 113 & 93 & 74 \\
\hline 95 & 207 & 95 & 145 & 95 & 142 & 95 & 104 \\
\hline
\end{tabular}


Thus, the TAA Gol and BRSMG Uai cultivars were harvested on January 25 (2018), whereas the Pérola cultivar and the VR 20 line were harvested on February 01 (2018). In all the experiments, the plants in the two central rows of each plot were manually uprooted and then mechanically threshed.

The grain yields were determined by harvesting the two central rows of each plot after standardizing the grain moisture to $13 \%$. The data were subjected to analysis of variance using the F test, in the Sisvar statistical analysis software (Ferreira 2011). The variables that showed significance at $5 \%$ by the $\mathrm{F}$ test were subjected to regression analysis.

To justify the choice of the NSI, the confidence interval of the regression analysis estimate was determined using the equation by Draper \& Smith (1966):

$C I R A E=\left\{\hat{\beta}_{0}+\hat{\beta}_{1} x 0 \pm t_{\left(1-\frac{\alpha}{2} ; n-2\right)} \sqrt{\operatorname{MSE}\left[\frac{1}{n}+\frac{(x 0-\bar{x})^{2}}{\sum_{i=1}^{n}\left(x_{i}-\bar{x}\right)^{2}}\right]}\right\}$

where: CIRAE is the confidence interval of the regression analysis estimate; $\hat{\beta}_{0}$ and $\hat{\beta}_{1}$ the regression coefficients; $x 0$ the value of interest for the sample; $t$ the tabulated value, Student's t distribution; $\alpha$ the significance level adopted; $n$ the total number of plots; MSE the mean square error; $x_{i}$ the observed values of the predictor variable; and $\bar{x}$ the mean value of the samples.

\section{RESULTS AND DISCUSSION}

The discrepancies between the NSIs observed at the time of the readings did not allow a joint analysis of the eight experiments, since they made the treatments personalized, as a function of the varied response of the sum of the cultivar and chlorophyll factors. This situation reveals, as a first result, the impossibility of adopting a generalized method for the indirect measurement of common bean leaf chlorophylls without considering the model of the device used and the genotype cultivated. Thus, the experiments were analyzed separately according to the genotype and device used. In both the experiments carried out with the TAA Gol cultivar, the grain yield responded linearly and positively to increases in the $\mathrm{N}$ dose applied as topdressing (Figures 1A and 1B), according to the experiments carried out with the SPAD-502 and CFL 1030 devices; however, the increase of $210 \mathrm{~kg}$ in the $\mathrm{N}$ dose, with the use of the SPAD 502, resulted in a variation of $380 \%$, while the variation for the CFL 1030 was $363 \%$, despite the increase in the dose being less than $150 \mathrm{~kg}$, proving again the distinct behavior of the devices. The observed results are similar to those found by Crusciol et al. (2007) and Moreira et al. (2013), who reported an increase in the grain yield of Carioca bean as a function of the increase in the $\mathrm{N}$ dose applied as topdressing.

Due to the impossibility of defining the NSI considered ideal for a cultivar only by regression analysis, another criterion was used to obtain the NSI considered appropriate for each device for the TAA Gol cultivar. Regression analysis determines the response trend of a trait as a function of treatment. However, by using the CIRAE, it is possible to infer at which point or points the evaluated trait differs significantly from those under other treatments (Draper \& Smith 1966). In a practical sense, for the present study, the common bean yields obtained with the various NSIs may be considered statistically equal, because they had overlapping CIRAEs.

Figures $1 \mathrm{~A}$ and $1 \mathrm{~B}$ show that, as the NSI increases, there is a positive response in grain yield, regardless of the chlorophyll meter used. However, according to the proposed methodology, considering the tested NSIs, it is recommended the smallest one, whose CIRAE overlapped the CIRAE obtained for the NSI of $95 \%$.

In the experiment with the TAA Gol cultivar and SPAD-502 apparatus, the NSI of $90 \%$ had values in common with the NSI of $95 \%$, considering their CIRAEs. For the grain yields evaluated with the CFL 1030 chlorophyll meter, the NSIs of 92 and $95 \%$ had overlapping CIRAEs (Figure 1B). Thus, the adoption of NSIs of 90 (SPAD-502) and $92 \%$ (CFL 1030) resulted in reductions of 75 and $45 \mathrm{~kg} \mathrm{ha}^{-1}$ of N, respectively, when compared to the $\mathrm{N}$ application rate corresponding to the NSI of $95 \%$ recommended by Silveira \& Gonzaga (2017).

The Pérola cultivar also showed a similar behavior in the experiments using the SPAD-502 and CFL 1030 chlorophyll meters (Figures 1C and 1D). In the experiment with the SPAD-502 chlorophyll meter, the NSIs of 90 and $95 \%$ had grain yield values in common according to the CIRAE equation (Figure 1C), since the confidence intervals of the two indices overlapped. Thus, the NSI of $90 \%$ was adopted as appropriate, and the $\mathrm{N}$ dose corresponding to this index was $197 \mathrm{~kg} \mathrm{ha}^{-1}$, which is quite high, when compared to the $\mathrm{N}$ doses used by producers. 

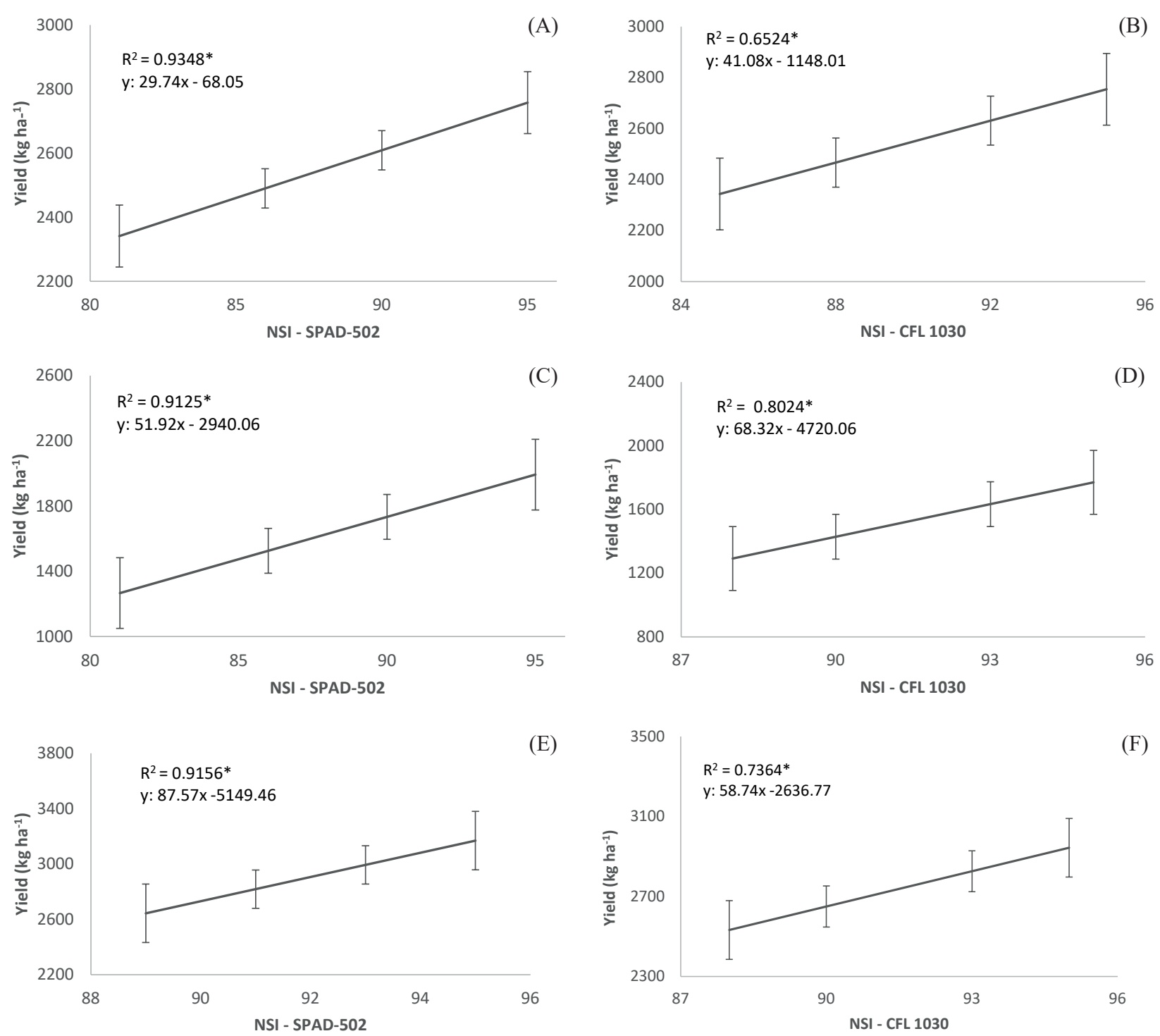

E)

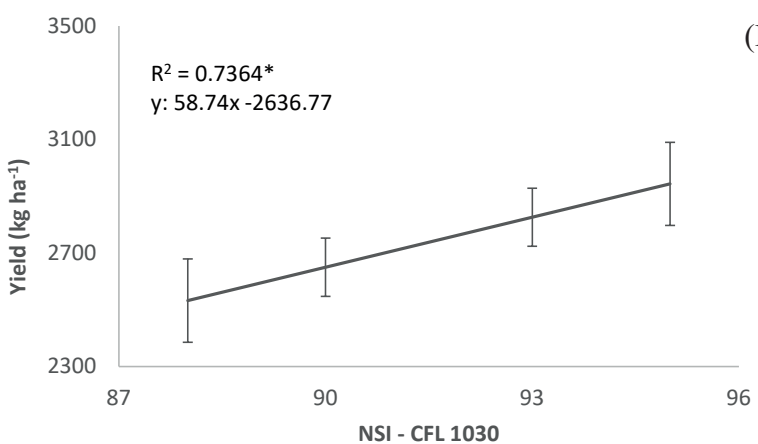

Figure 1. Grain yields of the common bean genotypes evaluated as a function of the nitrogen sufficiency index (NSI) defined with the aid of the SPAD-502 and CFL 1030 chlorophyll meters: (A) and (B): yields of the TAA Gol cultivar; (C) and (D): yields of the Pérola cultivar; (E): yield of the VR 20 line; (F): yield of the BRSMG Uai cultivar. * Significant at $5 \%$ by the t-test. The vertical bars indicate the confidence interval of the regression analysis estimate.

Binotti et al. (2009) observed increases in the yield of the Pérola cultivar greater than $2,700 \mathrm{~kg} \mathrm{ha}^{-1}$, until the application of $198 \mathrm{~kg} \mathrm{ha}^{-1}$ of $\mathrm{N}$, evidencing that this cultivar can be responsive to high $\mathrm{N}$ doses as topdressing, especially when grown on grass residue. Fornasieri Filho et al. (2007) reported a linear response in common bean yield $\left(2,400 \mathrm{~kg} \mathrm{ha}^{-1}\right)$ as a function of the application of $\mathrm{N}$ as topdressing at doses of up to $150 \mathrm{~kg} \mathrm{ha}^{-1}$. Menegol et al. (2015) found no differences for common bean yield $\left(2,061 \mathrm{~kg} \mathrm{ha}^{-1}\right.$ as an average yield) as a function of the $\mathrm{N}$ dose applied as topdressing up to $280 \mathrm{~kg} \mathrm{ha}^{-1}$.
The CIRAE of the NSI of $90 \%$ defined by the CFL 1030 chlorophyll meter for the Pérola cultivar overlapped with that of the NSI of $95 \%$ (Figure 1D). Thus, with the CFL 1030 chlorophyll meter, the NSI of $90 \%$ corresponded to a dose of $70 \mathrm{~kg} \mathrm{ha}^{-1}$ of $\mathrm{N}$, which is much lower than the $197 \mathrm{~kg} \mathrm{ha}^{-1}$ obtained with the SPAD-502 device. Moreover, the estimated yield obtained with the NSI of $90 \%$ determined with the CFL 1030 was $1,428 \mathrm{~kg} \mathrm{ha}^{-1}$, lower than that obtained with the SPAD-502 chlorophyll meter $\left(1,733 \mathrm{~kg} \mathrm{ha}^{-1}\right)$. However, in both cases, the yield was higher than the national average $\left(1,212 \mathrm{~kg} \mathrm{ha}^{-1}\right)$ and 
the Minas Gerais state average $\left(1,261 \mathrm{~kg} \mathrm{ha}^{-1}\right)$ for the same crop season (Conab 2019).

For the experiment conducted with the VR 20 line using the SPAD-502 chlorophyll meter, the grain yield varied linearly with increasing $\mathrm{N}$ doses of 29-119 $\mathrm{kg} \mathrm{ha}^{-1}$, as defined according to the evaluated NSIs (Figure 1E). These results are consistent with those reported by Crusciol et al. (2007), Valderrama et al. (2009) and Moreira et al. (2013), who applied up to $120 \mathrm{~kg} \mathrm{ha}^{-1}$ of $\mathrm{N}$ as topdressing and obtained a linear response for grain yield in common bean cultivars, always with yields above $2,400 \mathrm{~kg} \mathrm{ha}^{-1}$.

However, in addition to the regression analysis, the CIRAE was adopted, and overlapping CIRAEs were observed for the NSIs of 91,93 and $95 \%$. Thus, the adoption of the NSI of $91 \%$ resulted in reductions of 30 and $60 \mathrm{~kg} \mathrm{ha}^{-1}$ of $\mathrm{N}$, when compared to the NSIs of 93 and $95 \%$, respectively.

The $\mathrm{N}$ dose defined with the aid of the CFL 1030 chlorophyll meter, which varied between 29 and $104 \mathrm{~kg} \mathrm{ha}^{-1}$, had no effect on the grain yield of the VR 20 line, which showed an overall mean yield of 3,005 kg ha-1 (Table 2).

The obtained results are also in agreement with those reported by Arf et al. (2004) and Silva et al. (2006), since an increase in the $\mathrm{N}$ dose applied as topdressing in common bean did not increase the grain yield.

For the BRSMG Uai cultivar, when using the SPAD-502 chlorophyll meter, $\mathrm{N}$ doses ranging from 23 to $68 \mathrm{~kg} \mathrm{ha}^{-1}$ (defined according to their NSIs) did not significantly influence the grain yield (Table 3 ). This result was similar to those in the studies by Nascimento et al. (2004) and Silva et al. (2006), in which the increase of $\mathrm{N}$ doses applied as topdressing, with maximum doses of 90 and $120 \mathrm{~kg} \mathrm{ha}^{-1}$, respectively, had no significant effect on grain yield for Carioca common bean cultivars, with yields slightly higher than $2,000 \mathrm{~kg} \mathrm{ha}^{-1}$.

Table 2. Grain yield of the VR 20 common bean line as a function of the $\mathrm{N}$ dose corresponding to the nitrogen sufficiency index (NSI) determined from the CFL 1030 chlorophyll meter.

\begin{tabular}{ccc}
\hline NSI $(\%)$ & N dose $\left(\mathrm{kg} \mathrm{ha}^{-1}\right)$ & Yield $\left(\mathrm{kg} \mathrm{ha}^{-1}\right)$ \\
\hline 90 & 29 & 2,910 \\
92 & 59 & 3,105 \\
93 & 74 & 2,996 \\
95 & 104 & 3,011 \\
\hline
\end{tabular}

Thus, the NSI adopted as appropriate for the BRSMG Uai cultivar with the SPAD-502 chlorophyll meter was $92 \%$. This was the lowest index, with a grain yield statistically equal to those of the other NSIs tested. The obtained results differed from those presented by Silveira \& Gonzaga (2017), who reported that the ideal NSI for common bean plants is $95 \%$, when considering a fertilization factor between 11 and $15 \mathrm{~kg} \mathrm{ha}^{-1}$ of $\mathrm{N}$, for the Pérola cultivar and the CNPF 15874 line.

In the experiment with the CFL 1030 chlorophyll meter, the yield increased with increasing $\mathrm{N}$ doses, ranging from 37 to $142 \mathrm{~kg} \mathrm{ha}^{-1}$, according to the NSIs tested (Figure 1F). Leal et al. (2019) also obtained a positive response in grain yield for the BRSMG Uai cultivar with increasing $\mathrm{N}$ doses applied as topdressing. As discussed, in addition to the regression analysis, the CIRAE was used, and, because the CIRAEs of the NSIs of 93 and $95 \%$ overlapped, the NSI of $93 \%$ was considered appropriate for the BRSMG Uai cultivar.

The $\mathrm{N}$ dose corresponding to the NSI of $93 \%$ was $112 \mathrm{~kg} \mathrm{ha}^{-1}$, with yield of approximately $2,800 \mathrm{~kg} \mathrm{ha}^{-1}$, while the mean obtained in the experiment with the SPAD-502 device was $2,700 \mathrm{~kg} \mathrm{ha}^{-1}$. In both experiments, the obtained yields were higher than the overall mean of $2,361 \mathrm{~kg} \mathrm{ha}^{-1}$ determined from 27 experiments performed from 2007 to 2009 with this cultivar, according to Abreu et al. (2018).

The discrepancies among the NSIs found with the different devices and cultivars evaluated prevent a generalized recommendation for the use of chlorophyll meters without compromising the achievement of a higher efficiency for $\mathrm{N}$ fertilization. However, it is believed that the present study may contribute significantly to future studies on the use of chlorophyll meters to improve the efficiency of $\mathrm{N}$ fertilizers for common bean. The results show

Table 3. Grain yield of the BRSMG Uai common bean cultivar as a function of the $\mathrm{N}$ dose corresponding to the nitrogen sufficiency index (NSI) determined from the SPAD-502 chlorophyll meter.

\begin{tabular}{ccc}
\hline NSI $(\%)$ & N dose $\left(\mathrm{kg} \mathrm{ha}^{-1}\right)$ & Yield $\left(\mathrm{kg} \mathrm{ha}^{-1}\right)$ \\
\hline 92 & 23 & 2,659 \\
93 & 38 & 2,668 \\
94 & 53 & 2,687 \\
95 & 68 & 2,821 \\
\hline
\end{tabular}


the need of further data on the use of chlorophyll meters for genotypes with different traits, in different cultivation systems, to evaluate the performance of the devices in environments that strongly influence the plant $\mathrm{N}$ availability.

\section{CONCLUSIONS}

1. By using a fertilization factor of approximately $15 \mathrm{~kg} \mathrm{ha}^{-1}$ of $\mathrm{N}$, the appropriate nitrogen sufficiency index for common bean plants can be reduced to less than $95 \%$;

2. The choice of the appropriate nitrogen sufficiency index varies depending on the chosen common bean cultivar.

\section{REFERENCES}

ABREU, A. D. F. B.; RAMALHO, M. A. P.; CARNEIRO, J. D. S.; MELO, L. C.; PEREIRA, H. S.; SOUZA, T. L. P. O. de; VIEIRA, R. F. BRSMG Uai: cultivar de feijão tipo Carioca com planta de arquitetura ereta. Santo Antônio de Goiás: Embrapa Arroz e Feijão, 2018. (Comunicado técnico, 246).

AMADO, T. J. C.; MIELNIZUK, J.; FERNANDEZ, S. B. V. Leguminosas e adubação mineral como fontes de nitrogênio para o milho em sistemas de preparo do solo. Revista Brasileira de Ciência do Solo, v. 24, n. 1, p. 179189, 2000.

ARF, O.; RODRIGUES, R. A. F.; SÁ, M. E. de; BUZETTI, S.; NASCIMENTO, V. Manejo do solo, água e nitrogênio no cultivo de feijão. Pesquisa Agropecuária Brasileira, v. 39, n. 2, p. 131-138, 2004.

BARBOSA FILHO, M. P.; COBUCCI, T.; FAGERIA, N. K.; MENDES, P. N. Determinação da necessidade de adubação nitrogenada de cobertura no feijoeiro irrigado com auxílio do clorofilômetro portátil. Ciência Rural, v. 38, n. 7 , p. $1843-1848,2008$.

BARBOSA FILHO, M. P.; COBUCCI, T.; FAGERIA, N. K.; MENDES, P. N. Época de aplicação de nitrogênio no feijoeiro irrigado monitorada com auxílio de sensor portátil. Ciência e Agrotecnologia, v. 33, n. 2, p. 425431, 2009.

BINOTTI, F. F. da S.; ARF, O.; SÁ, M. E. de; BUZETTI, S.; ALVAREZ, A. C. C.; KAMIMURA, K. M. Fontes, doses e modo de aplicação de nitrogênio em feijoeiro no sistema plantio direto. Bragantia, v. 68, n. 2, p. 473-481, 2009.

CARVAlHO, M. A. de F.; SILVEIRA, P. M. da; SANTOS, A. B. dos. Utilização do clorofilômetro para racionalização da adubação nitrogenada nas culturas do arroz e do feijoeiro. Santo Antônio de Goiás: Embrapa Arroz e Feijão, 2012. (Comunicado técnico, 205).

COMPANHIA NACIONAL DE ABASTECIMENTO (Conab). Acompanhamento da safra brasileira de grãos: safra 2018/19: sétimo levantamento. 2019. Available at: https://www.conab.gov.br/info-agro/safras/graos/boletimda-safra-de-graos. Access on: Apr. 11, 2021.

COMPANHIA NACIONAL DE ABASTECIMENTO (Conab). Acompanhamento da safra brasileira de grãos: safra 2020/21: primeiro levantamento. 2021. Available at: https://www.conab.gov.br/info-agro/safras/graos/boletimda-safra-de-graos. Access on: Jan. 13, 2021.

CRUSCIOL, C. A. C.; SORATTO, R. P.; SILVA, L. M. da; LEMOS, L. B. Fontes e doses de nitrogênio para o feijoeiro em sucessão a gramíneas no sistema plantio direto. Revista Brasileira de Ciência do Solo, v. 31, n. 6, p. 1545-1552, 2007.

DRAPER, N. R.; SMITH, H. Applied regression analysis. New York: John Wiley \& Sons, 1966.

FERREIRA, D. F. Sisvar: a computer statistical analysis system. Ciência e Agrotecnologia, v. 35, n. 6, p. 10391042, 2011.

FORNASIERI FILHO, D.; XAVIER, M. A.; LEMOS, L. B.; FARINELLI, R. Resposta de cultivares de feijoeiro comum à adubação nitrogenada em sistema de plantio direto. Cientifica, v. 35, n. 2, p. 115-121, 2007.

HUSSAIN, F.; BRONSON, K. F.; YADVINDER, S.; SINGH, B.; PENG, S. Use of chlorophyll meter sufficiency indices for nitrogen management of irrigated rice in Asia. Agronomy Journal, v. 92, n. 5, p. 875-879, 2000.

LEAL, F. T.; FILLA, V. A.; BETTIOL, J. V. T.; SANDRINI, F. de O. T.; MINGOTTE, F. L. C.; LEMOS, L. B. Use efficiency and responsivity to nitrogen of common bean cultivars. Ciência e Agrotecnologia, v. 43, e004919, 2019.

MAIA, S. C. M.; SORATTO, R. P.; BIAZOTTO, F. de O.; ALMEIDA, A. Q. de. Estimativa da necessidade de nitrogênio em cobertura no feijoeiro IAC Alvorada com clorofilômetro portátil. Semina: Ciências Agrárias, v. 34, n. 5, p. 2229-2238, 2013.

MAIA, S. C. M.; SORATTO, R. P.; NASTARO, B.; FREITAS, L. B. de. The nitrogen sufficiency index underlying estimates of nitrogen fertilization requirements of common bean. Revista Brasileira de Ciência do Solo, v. 36, n. 1, p. 183-192, 2012.

MENEGOL, D. R.; PIAS, O. H. de C.; SANTI, A. L.; CHERUBIN, M. R.; BERGHETTI, J.; SIMON, D. H. Índice de suficiência de clorofila no manejo da adubação nitrogenada do feijoeiro comum. Revista Agroambiente On-line, v. 9, n. 2, p. 119-128, 2015. 
MOREIRA, G. B. L.; PEGORARO, R. F.; VIEIRA, N. M. B.; BORGES, I.; KONDO, M. K. Desempenho agronômico do feijoeiro com doses de nitrogênio em semeadura e cobertura. Revista Brasileira de Engenharia Agrícola e Ambiental, v. 17, n. 8, p. 818-823, 2013.

NASCIMENTO, M. S. do; ARF, O.; SILVA, M. G. da. Resposta do feijoeiro à aplicação de nitrogênio em cobertura e molibdênio via foliar. Acta Scientiarum. Agronomy, v. 26, n. 2, p. 153-159, 2004.

PELEGRIN, R. de; MERCANTE, F. M.; OTSUBO, I. M. N.; OTSUBO, A. A. Resposta da cultura do feijoeiro à adubação nitrogenada e à inoculação com rizóbio. Revista Brasileira de Ciência do Solo, v. 33, n. 1, p. 219-226, 2009.

SANTI, A. L.; DUTRA, L. M. C.; MARTIN, T. N.; BONADIMAN, R.; BELLÉ, G. L.; DELLA FLORA, L. P.; JAUER, A. Adubação nitrogenada na cultura do feijoeiro em plantio convencional. Ciência Rural, v. 36, n. 4, p. 1079-1085, 2006.

SANTOS, H. G.; JACOMINE, P. K. T.; ANJOS, L. H. C.; OLIVEIRA, V. Á.; LUMBRERAS, J. F.; COELHO, M. R.; ALMEIDA, J. A.; ARAÚJO FILHO, J. C.; OLIVEIRA, J. B.; CUNHA, T. J. F. Sistema brasileiro de classificação de solos. 5. ed. Brasília, DF: Embrapa, 2018.

SILVA, T. R. B. da; LEMOS, L. B.; TAVARES, C. A. Produtividade e característica tecnológica de grãos em feijoeiro adubado com nitrogênio e molibdênio. Pesquisa Agropecuária Brasileira, v. 41, n. 5, p. 739-745, 2006.

SILVEIRA, P. M. da; BRAZ, A. J. B. P.; DIDONET, A. D. Uso do clorofilômetro como indicador da necessidade de adubação nitrogenada em cobertura no feijoeiro. Pesquisa Agropecuária Brasileira, v. 38, n. 9, p. 10831087, 2003.

SILVEIRA, P. M. da; GONZAGA, A. C. de O. Portable chlorophyll meter can estimate the nitrogen sufficiency index and levels of topdressing nitrogen in common bean. Pesquisa Agropecuária Tropical, v. 47, n. 1, p. 1-6, 2017.

SOUSA, D. M. G. de; LOBATO, E. Calagem e adubação para culturas anuais e semiperenes. In: SOUSA, D. M. G. de; LOBATO, E. (ed.). Cerrado: correção do solo e adubação. Planaltina, DF: Embrapa Cerrados, 2004. p. 283-315.

UNITED STATES DEPARTMENT OF AGRICULTURE (USDA). Soil Survey Staff. Keys to soil taxonomy. 12. ed. Washington, DC: USDA, 2014.

VALDERRAMA, M.; BUZETTI, S.; BENETT, C. G. S.; ANDREOTTI, M.; ARF, O.; SÁ, M. E. de. Fontes e doses de nitrogênio e fósforo em feijoeiro no sistema plantio direto. Pesquisa Agropecuária Tropical, v. 39, n. 3, p. 191-196, 2009. 